Revista del Centro de Investigación de la Universidad La Salle

Vol. 13, No. 52, Julio-Diciembre, 2019: 67-82

DOI: http://doi.org/10.26457/recein.v13i52.2183

\title{
Molecular detection of bovine hemotrophic mycoplasmas in Mexico ${ }^{1}$
}

\section{Detección molecular de micoplasmas hemotróficos de bovinos en \\ México}

\author{
Rosa Estela Quiroz-Castañeda ${ }^{2}$ \\ CENID Salud Animal e Inocuidad, INIFAP (México) \\ Kytzya Mejía-Aragón \\ Universidad Politécnica del Estado de Morelos \\ Hugo Aguilar-Díaz \\ CENID Salud Animal e Inocuidad, INIFAP (México) \\ Jesús Francisco Preciado de la Torre \\ CENID Salud Animal e Inocuidad, INIFAP (México)
}

Recibido: 27 de junio de 2019

Aceptado: 12 de febrero de 2020

Publicado: 03 de junio de 2020

\section{Resumen}

La presencia de los hemoplasmas Candidatus Mycoplasma haemobos y Mycoplasma wenyonii que afectan al ganado bovino ha sido reportada durante los últimos años. Estos hemoplasmas pueden afectar la salud animal ya sea de forma independiente o en co-infecciones con otros microorganismos, lo que resulta en anemia entre otros signos clínicos.

${ }^{1}$ This work was partially financed with CONACyT grant PN 2014248855.

${ }^{2}$ Email: requiroz79@yahoo.com.mx 
Quiroz-Castañeda, R.; Mejía-Aragón, K.; Aguilar-Díaz, H.; Preciado de la Torre, J.

En México, solamente se había detectado a $\mathrm{Ca}$. M. haemobos en ganado bovino; en este trabajo, reportamos por primera vez en nuestro país, la presencia de los hemoplasmas $M$. wenyonii y $C a$. M. haemobos en animales provenientes de distintas zonas geográficas y los detectamos mediante un PCR dúplex. Adicionalmente, mediante PCR punto final, encontramos a $\mathrm{Ca}$. M. haemobos y M. wenyonii en el $96 \%$ y $96.29 \%$ de las muestras de sangre, respectivamente. Ambos hemoplasmas fueron detectados en el $70 \%$ de las muestras analizadas, esto es, en 17 de 24 muestras, lo que sugiere que el PCR dúplex desarrollado en este trabajo proveerá información valiosa para saber la condición de salud del ganado nacional para prevenir la dispersión del patógeno.

Palabras Clave: hemoplasmas, PCR dúplex, Mycoplasma wenyonii; ganado, métodos moleculares 


\section{Abstract}

The presence of hemoplasmas Candidatus Mycoplasma haemobos and Mycoplasma wenyonii that infect bovine cattle has been reported during the last years. Hemoplasmas may affect animal health either alone or in coinfections with other microorganisms, resulting in anemia and other clinical signs. In Mexico, only $\mathrm{Ca}$. M. haemobos has been detected in cattle; in this work, we report for the first time in our country the presence of $M$. wenyonii and $C a$. M. haemobos in animals from different geographical sources and we detected both hemoplasmas by duplex PCR. Also, by single end-point PCR, we found $C a$. M. haemobos and $M$. wenyonii in $96 \%$ and $96.29 \%$ of the blood samples, respectively. Both hemoplasmas were detected in $70 \%$ of the samples analyzed, this is, 17 out of 24 samples, which suggest that the duplex PCR developed in this work will provide valuable information to know the health condition of national cattle to prevent pathogen dispersion.

Keywords: hemoplasmas; duplex PCR; Mycoplasma wenyonii; cattle, molecular methods 
Quiroz-Castañeda, R.; Mejía-Aragón, K.; Aguilar-Díaz, H.; Preciado de la Torre, J.

\section{Introduction}

Animals are regularly exposed to a wide diversity of bacteria with the potential to cause diseases. Many times, these bacteria can establish associations with other bacteria increasing the risk of infection. The interest in hemotrophic mycoplasmas (also called hemoplasmas) is growing worldwide, primarily because of their detection by molecular methods (Kaewmongkol et al., 2017; Maggi et al., 2013).

Hemoplasmas are Gram-negative-pleomorphic bacteria, with small size (from 0.3 to $1 \mu \mathrm{m}$ in diameter) and small genomes (0.5-1.0 Mb). They are considered obligate epierythrocytic bacteria, so far uncultivable and may act as opportunistic agents, that silently infect animals (Messick, 2004). Hemoplasmosis may cause hematological disorders in several mammalian species, ranging from severe anemia to chronic infection without clinical signs. Those animals with acute infections may present hemolysis, anorexia, dehydration, fever, loss of weight, lethargy and even sudden death (Messick, 2004;Willi et al., 2007). Fleas, ticks, lice, and flies are responsible for the transmission of hemoplasmas in cats, dogs, mice, pigs, and cattle (Hornok et al., 2008; Seneviratna et al., 19731973; Willi et al., 2010). Although hemoplasmosis is not strictly considered a tick-borne disease, ticks might play a role in the epidemiology of these bacteria in cattle since some hemoplasmas are occasionally detected in ticks (Barker et al., 2010).

In Mexico, the genome of bovine hemoplasmas Candidatus Mycoplasma haemobos and Mycoplasma wenyonii have been reported (Martínez-Ocampo et al., 2016; Quiroz-Castañeda et al., 2018) and the presence of $\mathrm{Ca}$. M. haemobos was unknown until the first report of molecular detection of $\mathrm{Ca}$. M. haemobos in 2018 (Jaimes-Martínez et al., 2018). However, the presence of Mycoplasma wenyonii had not been reported. In this work, we present the first molecular detection in blood bovine of $M$. wenyonii by molecular methods based of end-point PCR and the detection of $C a$. M. haemobos and $M$. wenyonii in a duplex PCR reaction. In order to prevent dispersion of hemoplasmas in cattle, the development of diagnostic methods are necessary, especially when a limited number of hemoplasmas are suspected in animal blood. 


\section{Methodology}

\subsection{Genomic DNA extraction}

A total of 27 blood samples were used to extract genomic DNA (gDNA). Four samples from Huitzilac, Morelos (9936, 9938, 9939, 9940), nine from Tlaquiltenango, Morelos (Prieta Ajuchitlán, 3313856, 1700366161, 1700158415, 1700366176, 1700158415, 1700366175, 1700158423, Cuerno mocho), nine form Tapalpa, Jalisco (4701, 1162, 6802, 2914, 13R, 6760, $6747,4706,2904)$ and five from the Germplasm bank of Anaplasma Unit (CENID-SAI, INIFAP) (MEX-15-099-01, MEX-31-096-01, MEX-17-017-01, 0705, 3668). Blood samples were stored at $4^{\circ} \mathrm{C}$ until genomic DNA extraction with the kit ReliaPrep ${ }^{\mathrm{TM}}$ Blood gDNA Miniprep System (Promega). The extracted gDNA was quantified by spectrophotometry (NABI) and then analyzed by electrophoresis in $1 \%$ agarose gel.

1.2. Detection of Candidatus Mycoplasma haemobos and Mycoplasma wenyonii by Polymerase Chain Reaction

To detect $C a$. M. haemobos, a fragment of 492 bp of the 16 S ribosomal RNA was amplified by PCR according to (A Girotto et al., 2012). The primer sequences are: Mhfwd: 5'-ATC TAA CAT GCC CCT CTG TA -3' and Mhrev: 5'-GTA TTC GGT GCA AAC AA -3'. A fragment of 189 bp was amplified with the primers: Mwfwd: 5'-AGT CTG AGA TGA CTA TAG TG -3' and Mwrev: 5'-CGA GGC AAA CCC CGC AAG CA -3' that were designed based on the gene rnpB of $M$. wenyonii INIFAP02.

The PCR reaction contained $12.5 \mu \mathrm{L}$ of MyTaq Mix 2X (Bioline), $1 \mu \mathrm{L}$ of each primer (10 $\mathrm{pmol} / \mu \mathrm{L}$ ), and $300 \mathrm{ng}$ of gDNA as template and MiliQ water to a final volume of $25 \mu \mathrm{L}$. The PCR reaction conditions were: a first denaturation cycle at $94^{\circ} \mathrm{C}$ for three minutes, 35 cycles of denaturation at $94^{\circ} \mathrm{C}$ for 30 seconds, annealing at $58^{\circ} \mathrm{C}$ for 2 minutes and extension at $72^{\circ} \mathrm{C}$ for 1 minute, finally one cycle at $72^{\circ} \mathrm{C}$ for 10 minutes. For detection of $M$. wenyonii (INIFAP02) the conditions were: a first denaturation cycle at $94^{\circ} \mathrm{C}$ for three minutes, 35 cycles of denaturation at $94^{\circ} \mathrm{C}$ for 30 seconds, annealing at $57^{\circ} \mathrm{C}$ for 30 seconds and extension at $72^{\circ} \mathrm{C}$ for 30 seconds, finally one cycle at $72^{\circ} \mathrm{C}$ for 10 minutes. As negative control, DNA template was substituted by MilliQ 
Quiroz-Castañeda, R.; Mejía-Aragón, K.; Aguilar-Díaz, H.; Preciado de la Torre, J.

water. After PCR amplification, samples were observed by electrophoresis in $1 \%$ agarose gel stained with ethidium bromide.

\subsection{Duplex PCR for detection of Ca. M. haemobos and M. wenyonii}

The gDNA of the positive samples to $C a$. M. haemobos and $M$. wenyonii amplified by end-point PCR were used as templates for duplex reaction. This reaction amplifies both $492 \mathrm{bp}$ and $189 \mathrm{bp}$ fragments in the following conditions: $12.5 \mu \mathrm{L}$ of MyTaq Mix 2X (Bioline), $1 \mu \mathrm{L}$ of each primer $(10 \mathrm{pmol} / \mu \mathrm{L}), 300 \mathrm{ng}$ of gDNA and MilliQ water to a final volume of $25 \mu \mathrm{L}$. Amplification conditions were: an initial denaturation at $94^{\circ} \mathrm{C}$ for three minutes, 35 cycles of denaturation at $94^{\circ} \mathrm{C}$ for 30 seconds, annealing at $58^{\circ} \mathrm{C}$ for 2 minutes, extension at $72^{\circ} \mathrm{C}$ for 1 minuto and a last extension cycle at $72^{\circ} \mathrm{C}$ for 10 minutes. To test the sensitivity of the duplex PCR, $300 \mathrm{ng}$ of gDNA from MEX-31-096-01 was used as template and diluted 1:10, 1:100, 1:1000 and 1:1000 (corresponding to $30 \mathrm{ng} / \mu 1,3 \mathrm{ng} / \mu 1,0.3 \mathrm{ng} / \mu 1$ and $0.03 \mathrm{ng} / \mu 1$, respectively).

\subsection{Purification of PCR products for sequencing}

The amplicons of 492 bp and 189 bp were purified with the kit Wizard Gel and PCR Clean-Up System (Promega) and resuspended in $30 \mu \mathrm{L}$ of MilliQ water and then sequenced in Unidad de Síntesis y Secuenciación, IBT-UNAM.

\subsection{Propidium iodide staining}

The blood infected with hemoplasmas were stained with propidium iodide. 7-10 $\mu \mathrm{L}$ of blood were smeared on a slide and then the blood was gently fixed drop by drop with cold methanol at room temperature. The sample was gently washed drop by drop three times with tridistilled water. Later, $15 \mu \mathrm{g}(15 \mu \mathrm{L})$ of propidium iodide solution (stock $1 \mathrm{mg} / \mathrm{ml}$ ) were mixed with $485 \mu \mathrm{L}$ of PBS and then added drop by drop to the sample and dark-incubated for 10 minutes at room temperature. After incubation, the sample was washed three times with PBS as mentioned before and air-dried. The fluorescence of propidium iodide was observed in a epifluorescence microscope with an excitation/emission spectra of 493/636 nm. 


\section{Results}

\subsection{PCR amplification to detect Ca. M. haemobos and M. wenyonii}

Both hemoplasmas were detected in the blood samples of bovines from different geographic sources. The amplicons obtained after end-point PCR are shown in Figure 1. $\mathrm{Ca}$. M. haemobos was detected in 24 out of 25 blood samples (Figure 1A), while $M$. wenyonii was detected in 22 out of 27 blood samples (Figure 1B). The sequencing of amplicons and the multiple alignment of sequences (Clustal Omega) confirmed that the amplicon of 189 bp have a $100 \%$ of identity with M. wenyonii INIFAP02 while the amplicon of 492 bp have a range of identity of $96-100 \% \mathrm{Ca}$. M. haemobos INIFAP01. 
A

Huitzilac, Morelos

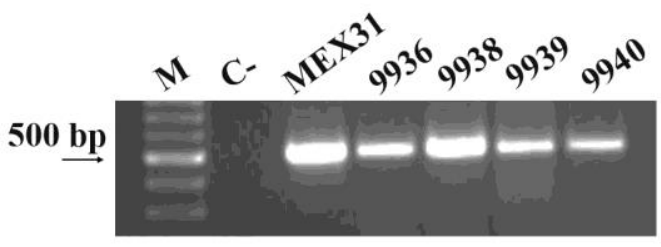

Tlaquiltenango, Morelos

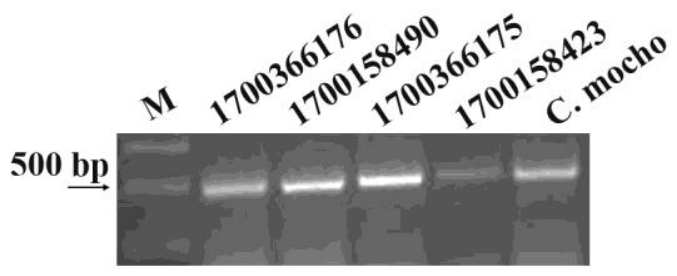

Tapalpa, Jalisco

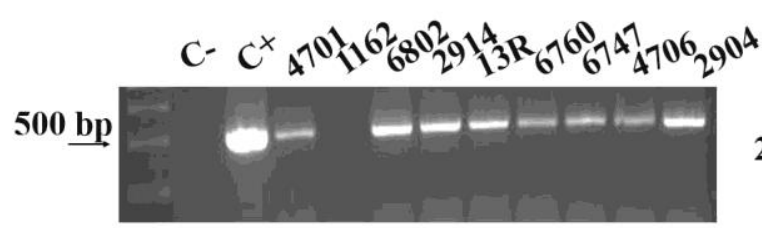

Germplasm bank

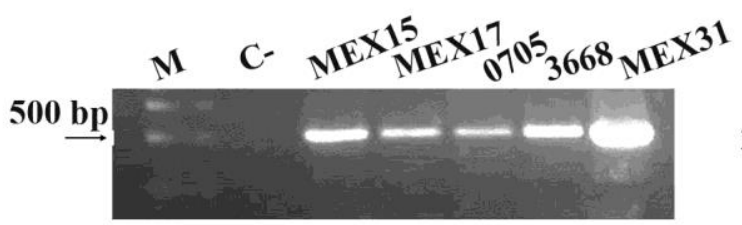

B

Huitzilac, Morelos

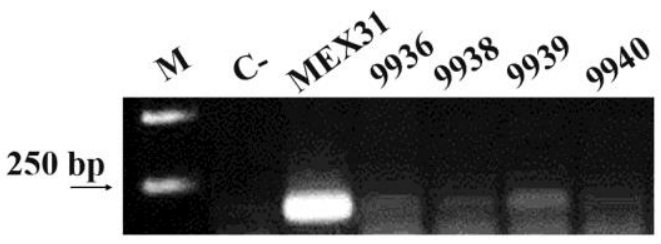

Tlaquiltenango, Morelos

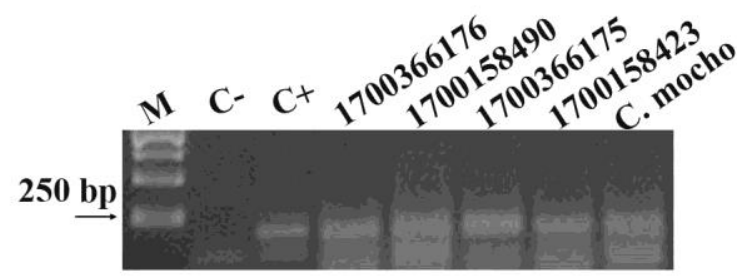

Tapalpa, Jalisco

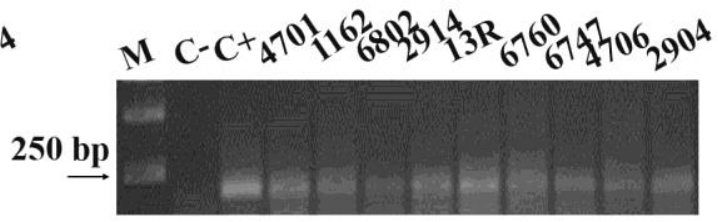

Germplasm bank

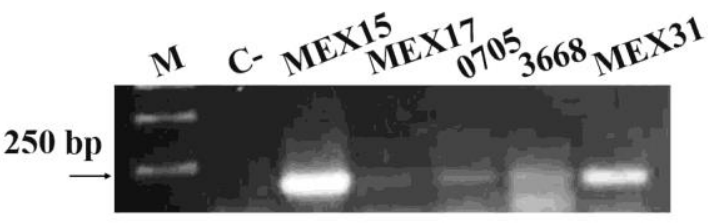

Figure 1. Molecular detection of $\mathrm{Ca}$. M. haemobos and M. wenyonii. A) PCR amplification of the fragment of $492 \mathrm{bp}$ of $16 \mathrm{~S}$ rRNA of $\mathrm{Ca}$. M. haemobos. This hemoplasma was detected in 24 out of 25 blood samples. B) PCR amplification of the fragment of $189 \mathrm{bp}$ of $r n p B$ gene of $M$. wenyonii detected in 26 out of 27 blood samples. M, molecular marker, $\mathrm{C}-$, negative reaction control. 


\subsection{Duplex PCR amplification to detect $\mathrm{Ca}$. M. haemobos and $\mathrm{M}$. wenyonii}

Some gDNA samples that were positive to $C a$. M. haemobos and M. wenyonii (MEX31, 1162, $4701,6802,2914,2904,1700366176,1700158490,1700366175)$ were used to perform the duplex PCR. Both ampicons of $189 \mathrm{bp}$ and $492 \mathrm{bp}$ were detected in 5 out of $10 \mathrm{gDNA}$ samples as is shown in Figure 2.
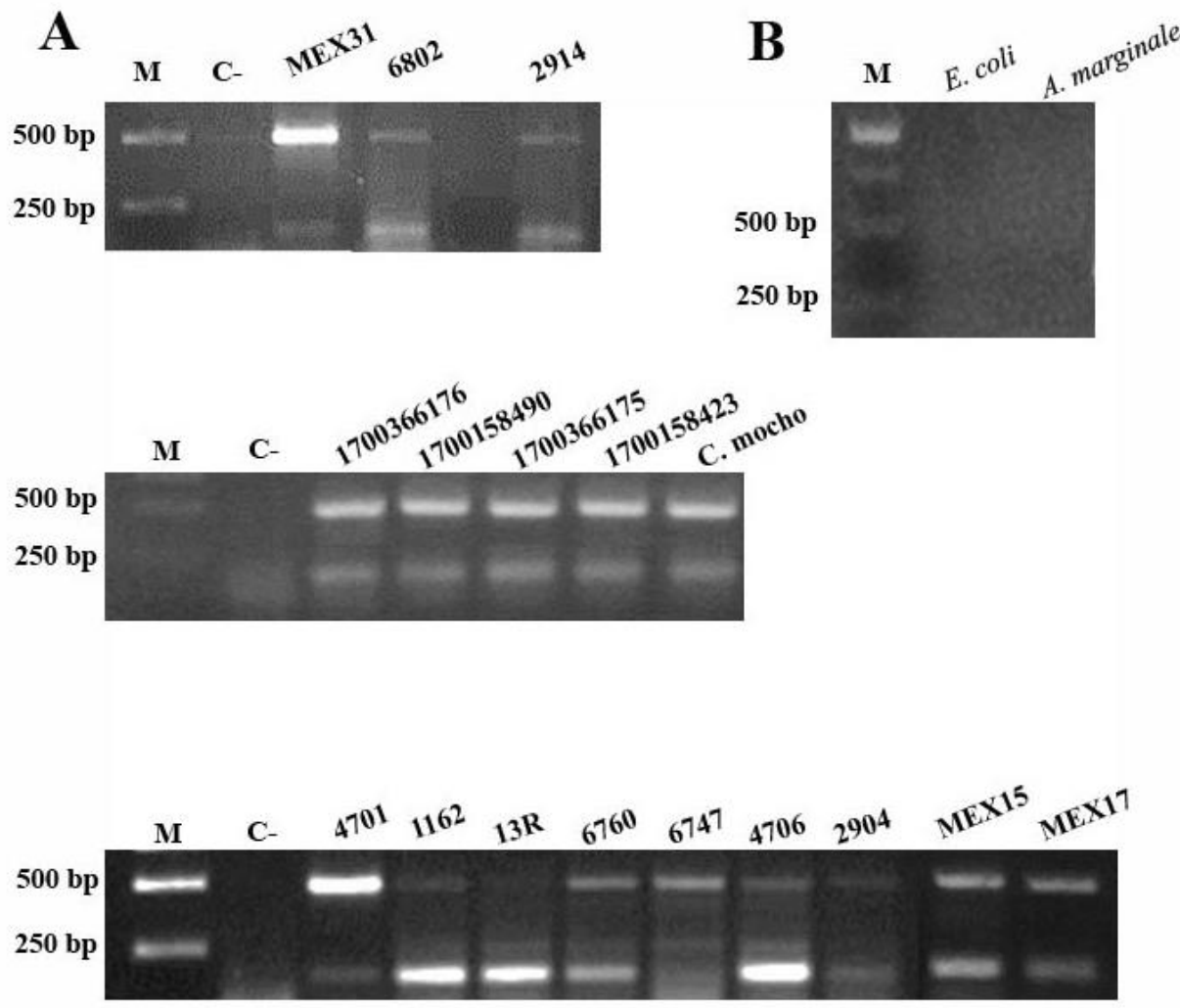

Figure 2. Duplex PCR to detect hemoplasmas. A) Amplicons of 189 bp and 492 bp detected by duplex PCR in 17 blood samples (MEX31, 6802, 2914, 1700366176, 1700158490, 1700366175, 1700158423, C. mocho, 4701,1162, 13R, 6760, 6747, 4706, 2904, MEX15, MEX17. B) Specificity of the duplex PCR, the genomic DNA used as template was from Escherichia coli and A. marginale, both, considered as pathogens of cattle. M, molecular marker, C-, negative reaction control. 
Quiroz-Castañeda, R.; Mejía-Aragón, K.; Aguilar-Díaz, H.; Preciado de la Torre, J.

\subsection{Sensitivity of duplex PCR}

The minumun detectable amount of gDNA of MEX-31-096-01 used in duplex PCR was in the dilution 1:10000, this is, $0.03 \mathrm{ng} / \mu 1$. Figure 3 shows that both amplicons are detected in dilutions 1:10, 1:100 and 1:1000. In dilution 1:10000 only the amplicon of $492 \mathrm{bp}$ was detected.

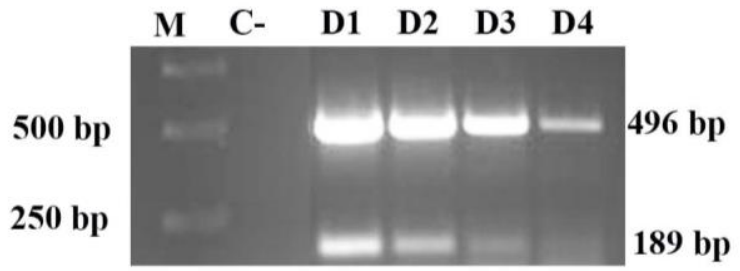

Figure 3. Sensitivity of duplex PCR. Both amplicons (189 bp and $492 \mathrm{bp}$ ) were detected in dilutions D1, D2 and D3 of gDNA from blood infected with $C a$. M. haemobos and $M$. wenyonii. (D1, Dilution 1:10, D2, Dilution 1:100; D3, dilution 1:1000; and D4, dilution 1:10000), M, molecular marker, $\mathrm{C}-$, negative reaction control.

\subsection{Propidium iodide staining of hemoplasmas}

Additionally to molecular detection of hemoplasmas, they were stained with propidium iodide to confirm microscopically their presence as epierythrocytic bacteria. We found that hemoplasmas are located outside the erythrocyte as has been reported as hemoplasmas, as is-shown in Figure 4. 


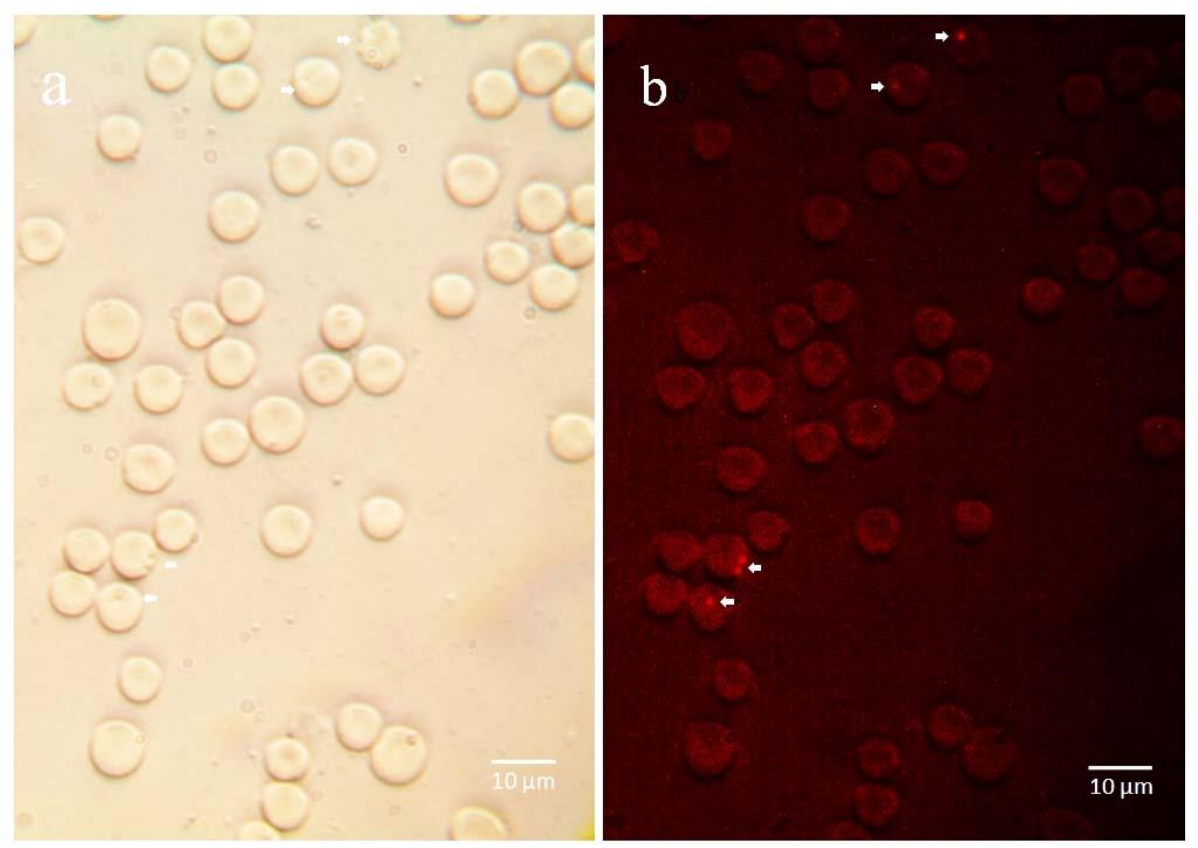

Figure 4. Representative micrograph of hemoplasmas stained with propidium iodide. M. wenyonii was detected as epierythrocytic pathogen. a) bright field of erythrocytes infected with hemoplasmas; b) hemoplasmas stained with propidium iodide are observed outside the erythrocytes.

\section{Discusion}

Bovine hemoplasmas, $C a$. M. haemobos and $M$. wenyonii have been detected in several countries around the world. In Latin America, they were reported in Mexico, Brazil and Cuba (Díaz-Sánchez et al., 2019; A Girotto et al., 2012; Jaimes-Martínez et al., 2018). The risk of coinfections of these hemoplasmas with other pathogens endanger the health of cattle and causes economical losses. In 2018, Ca. M. haemobos was detected in Mexican cattle by molecular methods, and sometimes this hemoplasma was found in co-infection with pathogen A. marginale (Jaimes-Martínez et al., 2018). Due to hemoplasmas can cause anemia, loss of weight, fever, edema, reproductive problems, mastitis and jaundice, their detection is the first step to characterize the agents present in the infected host (Ayling et al., 2012). Today, the use of molecular markers and their PCR amplification is the most accessible and common method to detect the presence of pathogens. Here, we report the molecular detection of hemoplasmas in blood samples from Mexican cattle. The blood samples come from different geographical locations, including, Morelos (Huitzilac, Tlaquiltenango, MEX17), Jalisco (Tapalpa), Estado de México (MEX15) and Yucatán (MEX31). 
Quiroz-Castañeda, R.; Mejía-Aragón, K.; Aguilar-Díaz, H.; Preciado de la Torre, J.

The presence of these hemoplasmas in these samples suggest that they are spread in our country. Nevertheless, a study with more samples is still required, especially in those states with a significant impact in cattle production as Veracruz, Tamaulipas, Sonora, Guanajuato and Michoacán. The detection of each hemoplasma (either $\mathrm{Ca}$. M. haemobos or $\mathrm{M}$. wenyonii) was based on end-point PCR while a duplex PCR detected both hemoplasmas. We found that amplification by PCR of the molecular marker $16 \mathrm{~S}$ ribosomal RNA gene allowed the detection of $\mathrm{Ca}$. M. haemobos in $96 \%$ of the blood samples analyzed. The rnpB gene was successfully used to detect M. wenyonii in $95.29 \%$ of the blood samples, as it was confirmed by sequencing identity (figure $1)$.

Both hemoplasmas were detected by duplex PCR in 17 blood samples (figure 2A), the design of the primers was specific to hemoplasmas, since amplicons were not observed in samples with gDNA from E. coli and A. marginale (figure 2B). Altough the development of detection methods based on duplex PCR requires optimization of primer annealing conditions, and enzyme and buffer concentrations for maximum amplification efficiency of each gene target, in this work, we were able to design a PCR reaction with two pairs of primers to detect hemoplasmas in cattle, in samples with as little as $0.03 \mathrm{ng}$ of gDNA (figure 3). The hemoplasmas stained with propidium iodide were observed on the surface of the erythrocytes (figure 4).

This is the first report of the detection of hemoplasmas in Mexican cattle based on endpoint PCR and the detection of $\mathrm{Ca}$. M. haemobos and $\mathrm{M}$. wenyonii in a duplex PCR. The conditions of duplex PCR allowed the detection of both hemoplasmas in 17 samples. With this approach to detect bovine hemoplasmas in Mexican cattle, veterinarians and authorities could be able to take decisions to avoid the spread of pathogens in cattle and decrese the risk of coinfections that may affect animal health.

\section{Conclusions}

Hemoplasmas found either alone or in co-infections become a risk to animal health. Hence, the importance to develop precise molecular tools for early detection of pathogens in cattle. In this work, we show the detection of both hemoplasmas that affect cattle by molecular methods. 


\section{Acknowledgements}

To Ms. C. Elizabeth Salinas Estrella for kindly provide some blood samples.

\section{References}

Ayling, R., Bisgaard-Frantzen, S., Adler, A., Blowey, R., Barlow, A., Millar, M., \& van der Burgt, G. (2012). Detection of Candidatus Mycoplasma haemobos, Mycoplasma wenyonii and Anaplasma phagocytophilum from cattle in England. Veterinary Records, 170(21), 543. http://dx.doi.org/10.1136/vr.100636

Barker, E. N., Tasker, S., Day, M. J., Warman, S. M., Woolley, K., \& Birtles, R. (2010). Development and use of real-time PCR to detect and quantify Mycoplasma haemocanis and 'Candidatus Mycoplasma haematoparvum' in dogs. Vet Microbiol, 140. https://doi.org/10.1016/j.vetmic.2009.07.006

Díaz-Sánchez, A. A., Corona-González, B., Meli, M. L., Álvarez, D. O., Cañizares, E. V., Rodríguez, O. F., Hofmann-lehmann, R. (2019). First molecular evidence of bovine hemoplasma species (Mycoplasma spp .) in water buffalo and dairy cattle herds in Cuba, 19. https://doi.org/10.1186/s13071-019-3325-y

Dieckmann, S. M., Hoelzle, K., Dieckmann, M. P., Straube, I., Hofmann-Lehmann, R., \& Hoelzle, L. E. (2012). Occurrence of hemotrophic mycoplasmas in horses with correlation to hematological findings. Vet Microbiol, 160. https://doi.org/10.1016/j.vetmic.2012.05.016

Girotto, A., Zangirolamo, A. F., Bogado, A. L. G., Souza, A. S. L. E., da Silva, G. C. F., Garcia, J. L., Vidotto, O. (2012). Molecular detection and occurrence of "Candidatus Mycoplasma haemobos" in dairy cattle of Southern Brazil. Revista Brasileira de Parasitologia Veterinaria = Brazilian Journal of Veterinary Parasitology: Orgao Oficial Do Colegio Brasileiro de Parasitologia Veterinaria, 21(3), 342-344. http://dx.doi.org/10.1590/S1984$\underline{29612012000300034}$

Girotto, A., Zangirólamo, A. F., Bogado, A. L. G., Souza, A. S. L., Silva, G. C. F., \& Garcia, J. L. (2012). Molecular detection and occurrence of `Candidatus Mycoplasma haemobos’ in dairy cattle of Southern Brazil. Rev Bras Parasitol, 21. https://doi.org/10.1590/S198429612012000300034

Hoelzle, K., Winkler, M., Kramer, M. M., Wittenbrink, M. M., Dieckmann, S. M., \& Hoelzle, L. 
Quiroz-Castañeda, R.; Mejía-Aragón, K.; Aguilar-Díaz, H.; Preciado de la Torre, J.

E. (2011). Detection of Candidatus Mycoplasma haemobos in cattle with anaemia. The Veterinary Journal, 187(3), 408-410. https://doi.org/10.1016/j.tvj1.2010.01.016

Hornok, S., Foldvari, G., Elek, V., Naranjo, V., Farkas, R., \& de la Fuente, J. (2008). Molecular identification of Anaplasma marginale and rickettsial endosymbionts in blood-sucking flies (Diptera: Tabanidae, Muscidae) and hard ticks (Acari: Ixodidae). Veterinary Parasitology, 154(3-4), 354-359. https://doi.org/10.1016/j.vetpar.2008.03.019

Jaimes-Martínez, C. A., Quiroz-Castañeda, R. E., Francisco, J., Torre, P., \& Amaro-Estrada, I. (2018). Detección molecular del hemoplasma Candidatus Mycoplasma haemobos en ganado bovino de México Molecular detection of hemoplasms Candidatus Mycoplasma haemobos in bovine cattle from Mexico. Acta Agrícola Y Pecuaria, 4(3), 99-107.

Kaewmongkol, G., Lukkana, N., Yangtara, S., Kaewmongkol, S., Thengchaisri, N., Sirinarumitr, T., Fenwick, S. G. (2017). Association of Ehrlichia canis, hemotropic Mycoplasma spp. and Anaplasma platys and severe anemia in dogs in Thailand. Veterinary Microbiology, 201, 195200. https://doi.org/10.1016/j.vetmic.2017.01.022

Machado, C. A. L., Vidotto, O., Conrado, F. O., Santos, N. J. R., Valente, J. D. M., Barbosa, I. C., Vieira, R. F. C. (2017). Mycoplasma ovis infection in goat farms from northeastern Brazil. Comparative Immunology, Microbiology and Infectious Diseases, 55, 1-5. https://doi.org/10.1016/j.cimid.2017.08.004

Maggi, R. G., Mascarelli, P. E., Havenga, L. N., Naidoo, V., \& Breitschwerdt, E. B. (2013). Coinfection with Anaplasma platys, Bartonella henselae and Candidatus Mycoplasma haematoparvum in a veterinarian. Parasites \& Vectors, 6, 103. https://doi.org/10.1186/17563305-6-103

Martínez-Ocampo, F., Rodríguez-Camarillo, S. D., Amaro-Estrada, I., \& Quiroz-Castañeda, R. E. (2016). Draft genome sequence of "Candidatus Mycoplasma haemobos," a hemotropic mycoplasma identified in cattle in Mexico. Genome Announcements, 4(4). https://doi.org/10.1128/genomeA.00656-16

McFadden, A., Ha, H. J., Donald, J. J., Bueno, I. M., van Andel, M., Thompson, J. C., ... Pulford, D. J. (2016). Investigation of bovine haemoplasmas and their association with anaemia in New Zealand cattle. New Zealand Veterinary Journal, 64(1), 65-68. 


\section{https://doi.org/10.1080/00480169.2015.1090356}

Messick, J. B. (2004). Hemotrophic mycoplasmas (hemoplasmas): a review and new insights into pathogenic potential. Veterinary Clinical Pathology, 33(1), 2-13. https://doi.org/10.1111/j.1939-165X.2004.tb00342.x

Nishizawa, I., Sato, M., Fujihara, M., Sato, S., \& Harasawa, R. (2010). Differential Detection of Hemotropic Mycoplasma Species in Cattle by Melting Curve Analysis of PCR Products. Journal of Veterinary Medical Science, 72(1), 77-79. https://doi.org/10.1292/jvms.09-0338

Quiroz-Castañeda, R. E., Martínez-Ocampo, F., \& Dantán-González, E. (2018). Draft Genome Sequence of Mycoplasma wenyonii, a second hemotropic Mycoplasma Species Identified in Mexican Bovine Cattle. Microbiology Resource Announcements, 7(9). Retrieved from http://mra.asm.org/content/7/9/e00875-18.abstract

Ravagnan, S., Carli, E., Piseddu, E., Da Rold, G., Porcellato, E., Zanardello, C., Capelli, G. (2017).

Prevalence and molecular characterization of canine and feline hemotropic mycoplasmas (hemoplasmas) in northern Italy. Parasites \& Vectors, 10, 132. https://doi.org/10.1186/s13071-017-2069-9

Satoh, H., Imai, D., Sato, S., Furuhama, K., \& Harasawa, R. (2016). Molecular detection of Mycoplasma haemomuris subspecies using dnaK-targeted real-time PCR with SYBR Green I and melting curve analysis. Molecular and Cellular Probes, 30(5), 291-293. https://doi.org/10.1016/j.mcp.2016.10.001

Seneviratna, P., Weerasinghe, \& Ariyadasa, S. (1973). Transmission of Haemobartonella canis by the dog tick, Rhipicephalus sanguineus. Research in Veterinary Science, 14(1), 112-114.

Willi, B., Boretti, F. S., Baumgartner, C., Cattori, V., Meli, M. L., \& Doherr, M. G. (2006). Feline hemoplasmas in Switzerland: identification of a novel species, diagnosis, prevalence, and clinical importance. Schweiz Arch Tierheilkd, 148. https://doi.org/10.1024/0036$\underline{7281.148 .3 .139}$

Willi, B., Boretti, F. S., Tasker, S., Meli, M. L., Wengi, N., Reusch, C. E., ... Hofmann-Lehmann, R. (2007). From Haemobartonella to hemoplasma: Molecular methods provide new insights. Veterinary Microbiology, 125(3-4), 197-209. https://doi.org/10.1016/j.vetmic.2007.06.027

Willi, B., Meli, M. L., Lüthy, R., Honegger, H., Wengi, N., \& Hoelzle, L. E. (2009). Development and application of a universal hemoplasma screening assay based on the SYBR Green PCR 
Quiroz-Castañeda, R.; Mejía-Aragón, K.; Aguilar-Díaz, H.; Preciado de la Torre, J.

principle. J Clin Microbiol, 47. https://doi.org/10.1128/JCM.01478-09

Willi, B., Novacco, M., Meli, M., Wolf-Jackel, G., Boretti, F., Wengi, N., Hofmann-Lehmann, R. (2010). Haemotropic mycoplasmas of cats and dogs: transmission, diagnosis, prevalence and importance in Europe. Schweizer Archiv Fur Tierheilkunde, 152(5), 237-244. https://doi.org/10.1024/0036-7281/a000055 